\title{
Minimal utopianism in the classroom
}

Emile Bojesen, University of Winchester and Judith Suissa, UCl Institute of Education

\section{Introduction: the architecture of minimal utopianism}

In a number of recent publications on the theme of utopian pedagogy, Darren Webb has explored the ways in which utopianism and the concept of "utopia" has lost some of its pejorative connotations and become part of mainstream academic discourse in educational research and theory. In noting the shift within this work away from the metaphor of the utopian architect, associated with utopian "blueprints", towards the metaphor of the archaeologist, Webb expresses the concern that "without a substantive normative vision to serve as a guide, utopian archaeology is conceptually flawed and practically ineffectual, romanticising an endlessly open process of exploration" (Webb, 2017, p. 552. See also Webb, 2016; 2009). We share Webb's view that

utopian pedagogy cannot limit itself merely to creating spaces - it is fundamentally concerned with what takes place within these spaces. And what takes place has to be something more than a series of radically open, always-unfinished exploratory encounters. Utopian pedagogy concerns itself with constructing visions of alternative ways of being, recognising that substantive programmatic visions of the future (blueprints) are needed in order to inspire and guide transformative hope and action. (2017, p. 562, original emphasis).

Yet while, like Webb, our focus is on the actual pedagogical practice suggested by a utopian orientation on the part of educators, we want to explore more closely the suggestion that a utopian pedagogy must be centrally concerned with drawing up blueprints. We suggest that, while Webb is correct to point out that blueprints, in the context of utopian thinking and practice, "do not arrive as an authoritarian imposition from above - they are the outcome of a long iterative process of consultation and collaboration" (ibid, p. 560), the positions and experiences of teachers in typical Higher Education classrooms in contemporary Britain 
suggest a far more qualified understanding of the role of the utopian pedagogue as the guide and director of "iterative process."

Our choice of the somewhat problematic term "minimal utopianism" is meant to reflect the practical insight that, while the conception of a "collective and collaborative process of memory- and story-making, pulling together - through a process of convocation and extrapolation - disparate inchoate dreams and yearnings in order to produce something new; a substantive utopian vision" (ibid, p. 562) may capture the pedagogical aspects of the utopian impulse involved in many informal educational experiments, social movement organizing and self-governing communities, it is rarely possible in the vast majority of Higher and Further Education institutions. The teaching contexts we have in mind are those, fairly typical in UK Universities, where lecturers teach a large group of undergraduate students, meeting them for one to two-hour weekly sessions over a period of a few months, as part of a structured degree programme. Many lecturers on social science, humanities or - our own area of expertise - education studies programmes, see the intellectual content of these courses as, at least in part, an opportunity to encourage their students to engage with new ideas, concepts, theories and perspectives that they may not have encountered previously, and to develop the theoretical resources and communicative tools (i.e. reading, writing, listening and speaking skills) to reflect critically on aspects of their social and political reality.

Unfortunately, in our reading, the architecturally-oriented utopian pedagogue, drawing on Webb's analysis, can find herself in an awkward position in such situations, in that, without a substantial period of time dedicated to consultation and collaboration with any particular group of students, the authority of any blueprint produced within the pedagogical encounter, even with the guidance and direction of the pedagogue, will be undermined. We do not, however, believe that the solution is to return to process-oriented utopian pedagogy, where role of the teacher is mainly to "open up spaces" and is thus seen as more practicable and less problematic. Instead, while rejecting, with Webb, the reduction of utopian pedagogy to "a method which takes the process of questioning, participation and dialogue as an end, not as a means" (Webb, 2009, p. 755), we want to offer an alternative conceptualisation of "what actually happens in those spaces" (p. 559).

Our suggestion is that rather than focusing on the requirement for the utopian pedagogue to consult and collaborate with a particular group of individuals, we accept that 
such work may be possible, in a less linear fashion, with several unconnected groups of students over long periods of time. Within this somewhat frustrating process, what the utopian pedagogue can develop, we suggest, is a kind of cumulative "utopian expertise", which informs her practice and her ability to help her students develop more informed dispositions towards the future and critical perspectives on the present. While our suggestion may not fully meet Webb's requirements for the iterative process of constructing utopian blueprints, it does, we suggest, contribute to the "convocation and extrapolation" that is part of this process. It does so in two ways: Firstly, through the pedagogical commitment to teaching about the possibility and the desirability of blueprint utopianism - a task we see as educationally prior to that of doing blueprint utopianism. Secondly, and connectedly, through the choice of content. For while utopianism involves, as Levitas notes, "the desire for a different, better way of being" (1990, p. 181), utopias are "explicitly holistic, imaginary, critical, normative, prescriptive" (Levitas, 2013, p. 84). In other words, the desire for a better way of being, for the utopian, goes hand in hand with the ability "to think holistically about the relationship between different social institutions, processes and areas of policy" (2004, p. 272). This, we suggest, is where the directive and normative role of the utopian pedagogue becomes crucial, for any holistic, imaginary vision of the future must surely be scaffolded by an ability to draw on a broad and rigorous conceptual landscape. So while utopian pedagogues, perhaps especially those situated in $\mathrm{HE}$, are not usually sufficiently able to consult and collaborate with any particular group of students in a sustained and effective manner, meaning that they are therefore not justified in proposing any particular blueprint, what they can do is teach the necessity and also the difficulty of constructing utopian blueprints, as well as tools useful for this work. Part of conveying both this necessity and this difficulty requires helping student to see how the frustrations, desires and aspirations they experience in their personal lives, including in the process of accessing and completing a university education, can be connected to broader political struggles.

In addition to its definition as a minimal form of blueprint utopianism, we also intend for the term "minimal utopianism" to signal several ideas that are particularly prescient in the current educational context. Primarily, that the disposition it requires is one of optimism on behalf of educators. Yet what we have in mind is not the retrieval of a "distinctive vocabulary of optimism about schooling and teaching and learning" as defended by David Halpin (2003, p.1) and rightly critiqued by Webb as suggesting an acquiescence with the political status quo 
where utopia is "debased, becoming little more than a coping mechanism." (2009, p. 749. See also Webb, 2016). The optimism we propose can be adopted by critical educators in the contemporary classroom is not a hopeful idealism which imagines that all will be well in due course, but rather an optimism which, as in Lionel Tiger's account (1979), "helps us to survive", and thereby optimises the actually existing space of the classroom and relations that exist within it to be able to make the individually and contextually specific "best" of them (see Bojesen, 2018). Yet at the same time, the hope implied by the utopian element of this orientation is the hope for and belief in the possibility of a radically better future, not confined to the kind of pragmatism reflected in the work of Giddens, Rorty and Halpin that, as Levitas argues in her review of Halpin's book (Levitas, 2004, p. 271; see also Webb, 2009) "serves to invalidate utopian speculation and imagination that departs substantially from the status quo, and to annihilate it discursively by claiming the space of utopia for reformism".

In defending optimism as optimisation we want to approach the task of exploring how "the transformative potential of Utopia" can be realized through "locating it in the future, thinking through the process of transformation from the present, and identifying the potential agents of that transformation" (Levitas and Sargisson, 2003, p. 13) in the limited and limiting context of Higher Education. What we want to suggest is that thinking about our informed stance as educators can help us to explore ways in which we can create, in the classroom, the conditions through which it becomes possible to imagine and explore alternatives to our current social and political reality and how these connect to the individual aspirations, desires and constraints that we face as individual educators and students. While we do not believe it is possible to engage sufficiently in blueprint or architectural utopianism, per se, in the classroom, we suggest that its importance and the necessary or basic conceptual and communicative tools for its practice can be taught and learned. Equally, we believe this can be accomplished without undermining the contingent ethical construction of role of the educator in the contemporary system within which they serve their students. That is to say, students can be provided with the resources for utopian architecture while being supported in meeting the, often outcome-oriented, demands of contemporary education, particularly in terms of assessment and grading. We recognise that this dual-faceted approach may be considered by some utopian theorists as too accommodating to the status quo, certainly in terms of its submission to contemporary systematically enforced educational exigencies, but perhaps also in its emphasis on providing resources for utopian thought and practice, rather 
than constructing or experiencing utopia. Our anticipation of these critiques is what leads us to describe this utopianism as "minimal". Another anticipated criticism is that our approach is, in fact, not utopian at all. To this we would compare what we suggest with the majority of non-utopian approaches present in contemporary academia, which neither engage with utopian content, let alone the significance of utopian architecture, nor frame the reading, writing, listening, and speaking skills developed in terms of their potential significance in utopian conceptualisation and implementation. Minimal utopianism is certainly less "fully" or "'maximally" utopian than either the archaeological form that Webb critiques or the architectural form he proposes, but it is also more utopian than an approach which only teaches utopian theory, or even just reading, writing, listening and speaking skills, without framing them as a means to longer term and extra-institutional blueprint utopianism. Equally, the practice of minimal utopianism in the classroom does not prohibit other forms of institutionally otherwise socially situated utopianisms and can exist alongside or in relation to them.

An educational orientation towards minimal utopianism has affinities with the utopianism of anarchist theorists that, as Suissa notes in her discussion of anarchist education (Suissa, 2009 p. 247) is "piecemeal" in the sense that it is concerned with "searching for, and fighting against, the greatest and most urgent evils of society, rather than searching for, and fighting for, its greatest ultimate good" (Popper, in Suissa, 2009, p. 247), yet is not pragmatist in the sense suggested by Halpin's work in that it insists on the needs of, and the possibility of, a radical and total challenge to existing social practices and institutions. If this radical challenge is to have real political consequences though, the utopian pedagogue needs to take seriously the idea that her role involves not just "opening up spaces" in the classroom for such radical imagination to emerge, but drawing on her disciplinary expertise in selecting, offering and discussing with students the kind of content, and helping to develop the skills, that can provide a conceptual and communicational toolkit for engaging in a radical critique of the present and imagination of the future.

\section{From radicalism to minimalism}

While we share Webb's insistence that utopianism must involve an orientation towards a substantive goal of radical social transformation, our focus here is on the prior educational task of allowing utopian thinking to emerge. The starting point for this task is the 
recognition that the means of utopian architectural thought need to be explicitly taught and even minimally enacted by Webb's (2017) "utopian pedagogue". For the question often faced by educators in contemporary $\mathrm{HE}$ classrooms is how to break through the apparent dominance of the discourse of no alternative in order to even begin to imagine the existence of radical alternatives. A significant element in encouraging students to begin the process of the "denunciation of the existing order of things and the annunciation of a utopian alternative" (Webb, 2017, p. 562) is often not just inviting students to explore their own desires and frustrations in order to articulate and criticise current forms of social injustice and oppression, but introducing a redefinition of taken-for-granted social ideas and structures in order to begin to see them differently. Our conception of minimal utopianism in the classroom thus confirms but also expands upon the definition given to teaching by the literary theorist and philosopher, Leo Bersani, for whom:

[teaching is] a sustained time and space where you do nothing but see how a group of people are going to connect. It's really extraordinary in that way. In teaching, a certain type of group-work can be done, which might slowly disseminate into a fairly significant part of society. It would be a matter of how modes of connectedness subtly change within society. (Bersani, 2010, p. 200).

The orientation we explore here is not simply a way of seeing the classroom as an "interstitial space" in which to begin to build an alternative future, but a way of cracking open the possibility of utopian imagining in the classroom itself, in terms of the direct and indirect effects our pedagogical practice can have on students' lives and on those to whom they are and will be related. As such, while the utopian pedagogue must not lose site of the "blueprint" element of her utopianism in the sense of the substantive normative values involved in reimagining social and political forms, the way in which this plays out in actual classroom interaction will involve the directive teaching of possibly very specific and contextual knowledge and conceptual tools coming from a disciplinary perspective. Any associated iterative process of constructive blueprints, then, will always be provisionally justified by experience and expertise, in the context of the classroom.

An example from a higher education context may help to illustrate what we mean here. One of us recently had the experience of teaching a session on feminist epistemology 
as part of an undergraduate philosophy module. In order to engage the students in a discussion about the implications of feminist work on "ways of knowing" and challenges to traditional epistemology on our social and educational practices, it was important to put this work in its historical context. In the course of explaining some central feminist concepts and theories, such as the social construction of gender, the ethics of care, and the political nature of the family, as well as offering a very brief overview of "first wave" and "second wave" feminism, we mentioned the feminist campaign for paid housework. In the ensuing discussion, a few students expressed a complete incredulity at the idea that domestic labour should or could be remunerated. But the process of thinking about why it is not, and what this says about how different kinds of work are regarded and the underlying view of society, opened up a discussion of far more far-reaching and radical questions about the nature and structure of the capitalist state, the meaning of work, and the possibilities for organizing society differently. The possibility of building on these insights for anything like the "long iterative process of iteration and consultation" described by Webb $(2017$, p. 56$)$ are practically non-existent in a context where course content is constrained by the structure of weekly lectures and the requirements of a demanding summative assessment regime. Yet at the same time, the utopian pedagogue does not have to abandon her role in "guiding and directing this process" (ibid) in the sense that what she does and says in the course of such discussions can help to orient students' thinking towards utopian horizons as part of a radical critique of the present, rather than conceiving this discussion as simply a means to fully understand theoretical perspectives as part of their academic formation. It can also orient the discussion towards holistic images of a possible future society rather than a piecemeal tinkering with current policy.

The preceding discussion should help to show that what is being proposed here is not a programme of step-by-step action to be taken, nor even a call for a radical change to existing practice, but rather a re-orientation; a way, perhaps, to think differently about what many often justifiably disillusioned educators may already be doing. This approach could be defined as a negotiation between the political and the ethical, the procedural and the relational, located specifically in the limited and limiting context of HE classrooms. Unlike those concerned with articulating philosophical accounts of education as an ethical "practice in its own right" with its own internal goods (see Dunne, 2005; Hogan, 2009, 2010, 2011), our view is that formal mass education is never not political. As such, instead of attempting to classify 
educational spaces as ethical rather than political, we argue that these spaces must navigate both. In this sense, our paper follows in the tradition of - or, perhaps, better, transmits along a similar frequency to - Maurice Blanchot's The Unavowable Community, which he intended to carry an "exacting political meaning" that "does not permit us to lose interest in the present time which, by opening unknown spaces of freedom, makes us responsible for new relationships, always threatened, always hoped for, between what we call work, oeuvre, and what we call unworking, desoeuvrement." (Blanchot, 1988: p. 56). The work of utopian reflection in and outside the classroom unworks contemporary social and political configurations, including those which establish our capacity for that unworking. In the light of this irresolvable contradictory relationship between the working and unworking of utopianism in the classroom and elsewhere, and for many of the same reasons Blanchot could not avow the concept of community - which is to say, provide a totalizing view, either of what it is ontologically or, as political utopia, should be - we find ourselves unable to convincingly argue for practicing anything but a minimal utopianism in HE classrooms. But, for us, the HE classroom is an example of a space where that contradiction can at least be navigated and negotiated - sometimes productively - rather than simply refused or limited to "creating spaces" (Webb 2017, p. 562).

\section{Minimal utopianism as pragmatic resistance}

What we are suggesting here is consistent with, but not restricted to, the view of educational spaces as sites for the kind of prefigurative practice described by many anarchist theorists, in which the means of revolutionary social change must be consistent with the ends. As Martin Buber famously expressed this idea:

The anarchist desires a means commensurate with his ends; he refuses to believe that in our reliance on the future 'leap' we have to do now the direct opposite of what we are striving for; he believes rather that we must create here and now the space now possible for the thing for which we are striving, so that it may come to fulfilment then; he does not believe in the post-revolutionary leap, but he does believe in revolutionary continuity. (Buber, 1958, p. 13). 
The concept of prefigurative practice is also associated with the idea of "building the new society in the shell of the old", exemplified in the anarchist tradition of theorists and activists such as Colin Ward, for whom anarchism, "far from being a speculative vision of a future society [...] is a description of a mode of human organization, rooted in the experience of everyday life, which operates side by side with, and in spite of, the dominant authoritarian trends of our society." (Ward, 1973, p.18).

Anarchists within this tradition have generally focused on how political agents already operating with a vision of a radically better society can work to construct this society through a gradual transformation of local and concrete spaces in spheres such as housing, education or allotments (see Ward, ibid). Yet our focus on the individual and contextual specificity of the HE classroom is not part of a utopian project to radically transform the university conceived as one of the "spheres of free action" that, in Paul Goodman's words, should be extended "until they make up most of social life", rather than strategically substituting a totally new order for the old order (Goodman, in Suissa, 2009, p. 247). It is not the university classroom as a prefigurative utopian space that we are emphasising here, but rather the university classroom as a place where utopian thinking can be facilitated and supported. Thus, the idea of utopia we draw on here resonates with the utopianism of the social anarchist tradition associated with thinkers such as Bakunin, Kropotkin and Landauer which, as Ruth Kinna has characterised it, involves not a "perfectionist, highly prescriptive or monistic attempt to delineate a vision of a better society", but a "way of thinking about qualitatively better states, opening up 'new conceptual spaces'”. (Kinna, 2009, p. 221). Crucially, although anarchist theorists disagree about the extent to which these two tendencies were present within classical anarchism, the understanding of utopianism we are reaching for here is not that associated with a programme of revolution as "emerging from social and economic contradictions and always deferred into the future", but, as Newman describes it, "utopianism as a disruption of the present that is also in the present" (Newman, 2009, p. 208). In the HE classroom, though, this "disruption" can often result from the introduction of conceptual distinctions and ideas which, as the above example illustrates, may allow the utopian pedagogue to entertain not much more than the modest hope that these ideas, alongside her utopian commitments and expertise in directing classroom discussion, can open up utopian horizons. While we agree with Webb that this hope embodies far more than the desire to enable "radically open, always-unfinished exploratory encounters" in our 
classrooms (Webb, 2017, p. 562), the way in which the utopian pedagogue draws on her expertise and substantive utopian values in directing such encounters must, and inevitably will, be mediated by the students' own experiences, desires, and vulnerabilities, and by the ethical obligation to engage with these as part of the pedagogical encounter.

Uri Gordon has theorised the role of utopia in anarchist theory and practice in light of the shift, in contemporary anarchism, from a resistance to the institutions of capitalism and the state to a more generalised resistance to all forms of domination in society (Gordon, 2009). Similarly, Blanchot writes of a "rupture with the powers that be, thus with the notion of power, thus with all places where power predominate." It was clear to Blanchot, as it is for us, that "this holds for the University, for the idea of knowledge, for the relation determined by a speech that teaches, that leads, and perhaps for all speech." (Blanchot, 2010, p. 88). As such, we aim to import the following rupture into the classroom, where

As soon as, through the movement of forces tending toward rupture, revolution appears possible, in a possibility that is not abstract but rather historically and concretely determined, it is in these moments, at these instants, that revolution takes place. Then there is a state of arrest and suspension. In this suspension, society undoes itself entirely. The law collapses. Transgression occurs: for a moment, there is innocence; interrupted history. (Blanchot, 2010, p.100).

This rupture is manifested in the classroom by the introduction of utopian content and the framing of what is learned (including reading, writing, listening, and speaking skills) in terms of its possible contribution to future utopian blueprints. It is, again, work as unworking, and does not avoid the contradictions of this logic (Blanchot, 1988: p. 56) and the (minimalist) implications they have for utopian classroom practice. It is important to note that the "rupture" described here is not an echo of the theory of revolutionary strategy favoured by most Marxists (and anarcho-communists), whereby the hoped-for and planned-for revolution is conceived of as "a single, cataclysmic break with past structures of oppression achieved by means of a violent seizure of state power." (Davis, 2012, p. 215). Nor is it simply an instance of the alternative approach described by Davis (ibid) as "exodus anarchism", where the emphasis is on "the construction of alternate institutions and social relationships in the hereand-now that will ultimately render the state and the capitalist market redundant" (ibid, p. 
213), and where revolution is conceived of not as a future event "but rather as a present-day process and a potential dimension of everyday life." (Gordon 2008, p. 41). We argue that aspects of this movement are minimally possible in the majority of mass educational settings as a form of "clandestine resistance out in the open" (Blanchot, 2010, p. 103). This resistance is made possible by a recognition of the malleability of present social and institutional arrangements - certainly, at least minimally, in the HE classroom itself - and a recognition of the importance of imagining alternatives. In this sense, then, the kind of disruption to common-sense conceptual frameworks described above can, for the utopian pedagogue, lead to critical discussions that can constitute a form of resistance to both the dominant narrative of "employability" that frames discussions of student engagement in the contemporary university, and to the alternative narrative of "enlightenment" or "liberation" familiar to students from encounters with the now almost ubiquitous critiques of the "neo-liberal university" and its associated instrumental conceptions of education. Such a stance is utopian in the sense described by Paul Goodman as "a pragmatic expediency that still wants to take the social structure as plastic and changeable" (Goodman, 1962, pp. 18-19).

\section{A context for minimal utopianism in practice: assessment}

A further example of the kind of pedagogical forms of disruption and resistance characteristic of the minimal utopianism we have in mind here can be found in the context of assessment. It is often around the dominant practice of assessment that student anxieties, as well as lecturers' resentments, come to the fore in the contemporary university. Academics committed to a view of the university as a place where intellectual engagement and criticality are seen as intrinsically valuable and self-evidently the main reason for going to university in the first place, are perhaps understandably frustrated at the amount of time, energy and effort they have to spend on providing clear instructions for assessment, complying with generic assessment requirements and regulations, and filling in all the paper-work involved in measuring and monitoring students' performance on standard assessment tasks. Students are - also understandably - anxious about the assessment requirements on their courses as so much hangs on the grades they receive. Against this background, demands on the part of students that that lecturers spend proportionately more class time explaining assessment procedures and offer students support and advice designed to help them improve their 
performance, can often create moments of tension rather than moments for productive relational experiences.

In the work of many critical educational theorists of "the neo-liberal university", the emphasis on standardized, transparent and easily measurable forms of assessment is seen as ideologically and casually linked to an instrumental view of education that is threatening, if not completely destroying an alternative, richer view of the value of knowledge and learning. As Singh puts it,

Teaching in the contemporary university is understood through a language of skills and competencies which, far from the ideological neutrality it claims, strips out ideas, replacing them with formulas. In effect students are deprived of the opportunity to encounter ideas and concepts materials through which they could gain a new or a deeper understanding of their experiences. This objectification of knowledge makes the neo-liberal university a dehumanised place where students experience of learning for students [sic] becomes a disenchanting process of 'playing the game', of managing to obtain a $2: 1$ by doing the least amount of reading and (deep) thinking as possible [...] (Singh, 2010, p. 5)

The problem with this approach, however, is that encouraging critical academics to resist the neo-liberal university, by refusing to "play the game" with their students, risks downplaying the significance for many, if not most, of the students in our classes, of the difference between graduating with a 2:1 or a 2:2 and failing to do so. It hardly needs stating that the reading, writing, listening and speaking skills often concomitant with those grades, are a real-life need for individuals as social actors. In an age when growing numbers of young people face the very real prospect of joining the ranks of the "precariat", and when there is fierce competition for even the most basic jobs - jobs that did not used to but now do require an undergraduate degree - ideals of learning and knowledge for its own sake may ring rather hollow with students.

Similarly, the argument that "There is also a risk that the provision of quantifiable information [that] serves to commodify education while presenting a direct link between education and employment may encourage prospective students to adopt an instrumental approach to their education" (Naidoo and Williams, 2015, p. 214) seems to ignore the fact 
that, in a capitalist economy with a state-run education system where educational qualifications are linked to positions in an unequally structured labour market, there has always been, and always will be, a direct link between education and employment. Acknowledging the positional good of education requires acknowledging the inevitability of an instrumental approach to education as an entirely rational attitude on behalf of many, if not all, students.

It may well be that part of the project of opposing the negative consequences of the state capitalist system that structures these educational processes and experiences will involve "creat[ing] learning and teaching environments in formal and informal educational spaces that facilitate dialogue, reflexivity and connection to real life needs and that enable the creation of methodologies encouraging and realising more democratic practices" (Singh, 2010, p.7), and this is perhaps best done in the kind of self-managed initiatives run outside the state system ${ }^{1}$. It may well be too that it is possible, as indeed critical educators have been doing for years, to create space for these kinds of pedagogical practices within the structures of the (neo-liberal) university. We are not denying the value or the possibility of such practice. What we are suggesting is that rejecting the political values underlying many contemporary university practices and forms of governance should not mean rejecting the instrumental value of what we, as employees of the university, have to offer our students, in the name of some ideal vision of what we are actually here for. Acknowledging this context is what leads us to describe the role of the utopian pedagogue in higher education as a far more modest and minimal one than the rejection of process-oriented utopian pedagogy may at first imply. It is also behind our insistence on foregrounding the ethical obligations we have to our students, both in terms of focusing on the substantive content that our academic expertise puts us in a position to elucidate and critique, and in terms of the need to never lose sight of the question of what our students need from us.

\section{Minimal utopianism in practice: strategic solidarity}

\footnotetext{
${ }^{1}$ See for example the Torontofreeskool: https://torontofreeskool.wordpress.com/tag/toronto/ or the Lincoln Social Science Centre http://socialsciencecentre.org.uk/. For a discussion of many such examples, see Elmore and Haworth (2017).
} 
If we were to believe the fantasy that graded summative assessment which contributes to a final grade for the student were simply a means of holding the student to account for the education they have received rather than their ability to succeed in dominant forms of assessment, then criticisms such as Singh's might be valid. However, this criticism does not hold up, given that from relatively early years in compulsory schooling, children will have been taught to learn and work towards the assessment, rather than be assessed on relatively unrestricted learning. This habit does not often or easily disappear and, perhaps unfortunately, it could potentially be detrimental to university students' grade portfolio to teach them to unlearn this approach. While critics of neo-liberal reforms to HE argue that the student-teacher relationship is undermined by the positioning of students as consumers, what we are suggesting is that we recognise the possibly detrimental effect on students of a refusal to prioritise their focus on grades and assessment. Such a refusal risks undermining the possibility of being able to forge relationships of solidarity with students as part of the kind of minimal utopianism we are arguing for. Our conception of the minimal role of the utopian pedagogue positions teachers not as advocates of a fully worked-out alternative future or representatives of a longed-for past. Nor do we necessarily believe, with Webb, that it is possible, in the context of the HE classroom, to see ourselves as co-creators and coimaginers, through a lengthy iterative process with our students, of utopian blueprints. What we can do is to help our students imagine new ways of being in the world that acknowledge their needs and desires to negotiate the socio-economic contingencies that have, for most if not all of them, led them to be in the university in the first place, while insisting on the necessity and possibility of recognising these contingencies as exactly that: contingencies, and, as such, malleable and open to radical change through collective human action. This is a prior and educationally crucial step to the construction of any utopian vision that can play a motivational and critical role.

This is where we again see the relevance of a notion of solidarity, which we refer to here as strategic solidarity, and which we argue constitutes a more pedagogically valuable way of working within the contemporary university than the critical stance that begins from the assumption that because most of our students are there simply to get a degree, their subjectivities are at odds with the forms of subjectivity that we envisage as constitutive of life in the "ideal" university. Instead of expecting them to be something they are not, we instead stand in solidarity with them in refusing to allow the prominent social narratives on education 
- e.g. that it is above all, an essential path to individual and social liberation; an induction into intrinsically worthwhile activities, or a guarantee of flourishing liberal democracy - to dominate the classroom. These narratives can be actively avoided and even directly challenged through the content and discussion in the classroom. Such a disposition does not imply the rejection of the idea that there is something valuable to be gained from the experience of higher education; but it does mean rejecting the idea that this value is derived from an ideal and a narrative that positions us, by virtue of our knowledge and expertise, as representatives of some higher plane of enlightenment or liberation. In refusing such narratives, we are not abandoning the inherent responsibility of the pedagogical relationship but prioritising what Blanchot describes as "an irreducible refusal, the friendship of this sure, unshakeable, rigorous No that unites them and determines their solidarity." (Blanchot, 2010, p. 7).

Jose Medina (2013) has developed an account of what he refers to as "radical solidarity" that he describes as requiring epistemic qualities and processes including, crucially, the willingness and the ability to expand our imagination so as to acknowledge other lives and other experiences (p. 267). Yet while what we are proposing here has similarities with Medina's idea in that it constitutes "an ethics and a politics of acknowledgement" (ibid), we are proposing this stance on the part of educators not primarily as a way to improve "forms of social relationality" so as to "meliorate democratic life" (ibid), but rather as a means to open up a pedagogical space in which there are multiple possibilities of interruption and refusal -including, perhaps, a refusal of the prevailing (liberal, statist) ideal of democratic life. Something as straightforward as a hypercompliance to assessments and learning outcomes in our classrooms offers a way of putting the teacher on the side of the students' interests. Instead of seeing oneself as being separated from or opposed to students, the educator would instead be on their side. Students are, in fact, more likely to feel able to work with their lecturers and tutors and engage with their teaching when they perceive them as operating "with them" in this way, rather than as implicitly or explicitly distancing themselves from the logic of current higher educational practices in the name of a nostalgic longing for some longgone ideal of the university as a site of liberal learning or a community of scholars. And we should not forget that our access to minimal utopianism necessitates this strategic solidarity; a strategic solidarity where we are not just allies of the students, but their accomplices in 
challenging and offsetting the constructions of the "autonomous" rather than interdependent subject that contemporary mass education often seems to attempt.

While we are not rejecting the idea that at least part of the role of the teacher - in HE as in other areas - is to "form new wants and interests, new possibilities of satisfaction - and, of course, of dissatisfaction" - and to "go beyond what [the student] knows" (Staddon and Standish, 2012, p. 300), we want to suggest that this cannot form the sole aim and rationale for how we act and how we teach, framed by a different, maximally utopian ideal of what the university "really" is or should be, or by a belief in the inherent value of our own discipline and intellectual interests. To do so would be to risk not only increasing our own frustration and dissatisfaction, but, crucially, alienating the majority of students who are not in university for anything like "engagement in a public dialectic" (Holligan and Shah, 2017) and who simply want to get the degree they are paying for so that they can get on with what they want to do in life. Of course, this position should not discourage educators from engaging with radical political ideas and theories that are more "maximally" utopian in the course of their teaching, but we suggest that the minimally utopian approach we propose constitutes a more fruitful, and a more practically feasible, pedagogic starting point. We would argue that this disposition is better able to take seriously our actually existing relationships with our students, rather than what we might hope they were. To the extent that it involves a kind of utopian thinking, it does so in the sense described by Ruth Levitas, who, drawing on the work of Tom Moylan, writes of critical utopias, where "utopia itself is presented ambiguously as imperfect, subject to difficulties, inconsistencies, faults, change. And utopia is not a necessary outcome of the present but a possible future, which may or may not be achieved." (Levitas, 1990, p. 172).

\section{Conclusion}

In an analysis that echoes some of the critiques of neo-liberalism mentioned here, Zygmunt Bauman comments that "we tend to be proud of what we perhaps should be ashamed of; of living in the 'post-ideological' or 'post-utopian' age, of not concerning ourselves with any coherent vision of the good society and of having traded off the worry about the public good for the pursuit of private satisfactions" (Bauman, 1999, p. 8). Although we are wary of the idea of a necessarily "coherent" vision of the good society, we do want to agree with Bauman here on the need, as part of an attempt to imagine and bring about less 
oppressive and unjust political arrangements, to think about the public good as opposed to only private satisfactions. From an educational point of view, the form of strategic solidarity with students that we are suggesting can perhaps be seen as a necessary first step towards thinking together about how our private satisfactions can themselves be understood through the lens of both existing and possible political and social values and arrangements. It is no use positing an imagined, ideal public good (the ideal university; the fully democratic society) as an alternative to private satisfactions; rather, we suggest, our private satisfactions and desires are central to the context in which we work, whether as educators doing our jobs, or as students getting our degrees.

While many critics of the so-called neo-liberal university seem to posit an underlying ideology in which individual freedom and choice take priority, as diametrically opposed to an alternative, humanistic worldview based on ideals of communality and sociability, we want to suggest that this is a misleading and unhelpful dichotomy. For as Laurence Davis has argued in his analysis of Bookchin's polemical rejection of "life-style anarchism" (Davis, 2010), "individualism and collectivism are in constant tension" not just within anarchist thought, but in any functioning free society. Crucially, this tension can be a potentially creative and constructive one. Pedagogically, it is perhaps through acknowledging this tension and exploring it with students, rather than resolving it by plumping for one or another familiar ideological position, that we can engage in utopian pedagogical practice in the HE classroom, however minimal. The aim of this is to allow educators and students to see the pedagogical space of the classroom as one in which hopeful possibilities can emerge in reality (see Suissa, 2010 and Bojesen, 2018) rather than exist only as process.

Thus, we claim, the question we should be asking ourselves as educators critical of the political reality in which we find ourselves, is not - or at least not primarily - "How can we resist this reality by positing a very different ideal of what the university can be?", but "How can we best work with our students, in the contexts available to us, towards helping them to appreciate the desirability and the possibility of utopian thinking as a necessary step towards a better future?"

\section{References}


Bauman, Z. (1999) In Search of Politics, Stanford: Stanford University Press.

Bersani, L. (2010) Is the Rectum a Grave?, Chicago and London, Chicago University Press.

Blanchot, M. (2010) Political Writings, 1953-1993, New York, Fordham University Press.

Blanchot, M. (1988) The Unavowable Community, Barrytown, Station Hill.

Bojesen, E. (2018) "A New Version of Optimism for Education", Studies in Philosophy and Education, 37:1, pp. 5-14. https://doi.org/10.1007/s11217-016-9560-1

Buber, M. (1958) Paths in Utopia, Boston: Beacon Press.

Davis, L. (2012). "Anarchism and the Future of Revolution." In Ruth Kinna (ed.) (2012), The Continuum Companion to Anarchism, pp. 212-232.

Davis, L. (2010) "Social Anarchism or Lifestyle Anarchism; An Unhelpful Dichotomy", Anarchist Studies, 18: 1, pp. 62-82.

Dunne, J. (2005) "What's the good of education?" in W. Carr (ed.) The RoutledgeFalmer Reader in Philosophy of Education, Abingdon: Routledge, pp. 145-160.

Elmore, J. and Haworth, R. (2017) Out of the Ruins; The Emergence of Radical Informal Learning Spaces, Oakland: PM Press).

Goodman, P. (1962) Utopian Essays and Practical Proposals , pp. 18-19.

Gordon, U. (2009) "Utopia in Contemporary Anarchism", in Laurence Davis and Ruth Kinna (eds.) Anarchism and Utopianism, Manchester: Manchester University Press.

Gordon, U. (2008) Anarchy Alive! Anti-Authoritarian Politics from Practice to Theory. London/Ann Arbor MI: Pluto Press. 
Halpin, D. (2003) Hope and Education: The Role of the Utopian Imagination, London and New York, RoutledgeFarmer

Hogan, P. (2011) "The ethical orientations of education as a practice in its own right", Ethics and Education, 6 (1), 27-40

Hogan, P. (2010) "Preface to an ethics of education as a practice in its own right", Ethics and Education, 5 (2), 85-98

Hogan, P. (2009) The New Significance of Learning: Imagination's Heartwork, London: Routledge.

Holligan, C. and Shah, Q. (2017) Global capitalism's Trojan Horse: Consumer power and the National Student Survey in England, Power and Education

Kinna, R. (2009) "Anarchism and the Politics of Utopia", in Laurence Davis and Ruth Kinna (Eds) Anarchism and Utopianism, Manchester University Press.

Kinna, Ruth (ed.) (2012). The Continuum Companion to Anarchism. London/NY: Bloomsbury Academic.

Levitas, R. (2013) Utopia as Method: The Imaginary Reconstitution of Society (Abingdon, Palgrave).

Levitas, R. (2004) "Hope and Education", Journal of Philosophy of Education, 38:2, pp. 269273).

Levitas, R. (1990) The Concept of Utopia, Syracuse, Syracuse University Press. 
Levitas, R. and Sargisson, L. (2003) Utopia in Dark Time: Optimism/Pessimism and Utopia/Dystopia, in Raffaella Baccolini and Tom Moylan (Eds) Dark Horizons; Science Fiction and the Utopian Imagination, New York and London, Routledge.

Medina, J. (2013) The Epistemology of Resistance, Oxford University Press.

Naidoo, R. \& Williams, J. (2015) "The neoliberal regime in English higher education: charters, consumers and the erosion of the public good", Critical Studies in Education, 56:2, pp. 208223.

Newman, S. (2009) "Anarchism, Utopianism and the Politics of Emancipation", in Davis and Kinna (eds.) Anarchism and Utopianism, Manchester: Manchester University Press.

Singh, G. (2010) "The Virtues and Vices of Teaching and Learning in Higher Education Today", paper presented at Oxford Brookes University Learning and Teaching Conference: Building networks, partnerships and communities 25th June 2010. (https://www.brookes.ac.uk/services/ocsld/resources/learn_teach_conf/bsle/conf10/singh _paper.pdfa, accessed 25.8.17)

Staddon E and Standish P (2012) "Improving the student experience". Journal of Philosophy of Education 46(4): 631-648.

Suissa, J. (2009) "'The space now possible' : anarchist education as utopian hope", in Davis and Kinna, Eds. Anarchism and Utopianism.

Tiger, L. (1979) Optimism: The Biology of Hope, New York: Simon and Schuster.

Ward, C. (1973) Anarchy in Action London: Allen \& Unwin.

Webb, D. (2017) "Educational archaeology and the practice of utopian pedagogy", Pedagogy, Culture \& Society. 25(4). 551-566. 
Webb, D. 2016. "Educational Studies and the Domestication of Utopia." British Journal of Educational Studies 64 (4): 431-448

Webb, D. (2009) "Where's the vision? The concept of utopia in contemporary educational theory", Oxford Review of Education, 35: 6, 743-760. 